\title{
Effect of Integrated Nutrient Management on Yield and Yield Components of Food Barley (Hordeum vulgare L.) in Kaffa Zone, Southwestern Ethiopia
}

\author{
Mitiku Woldesenbet ${ }^{1,2^{\star}}$, Tamado Tana ${ }^{2}$, Singh $\mathrm{TN}^{2}$, and Teferi Mekonnen ${ }^{3}$ \\ ${ }^{1}$ Mizan-Tepi University, Department of Plant Sciences, Post Box No: 260, Mizan Teferi, Ethiopia \\ ${ }^{2}$ Haramaya University, School of Plant Sciences, Post Box No: 138, Dire Dawa, Ethiopia \\ ${ }^{3}$ School of Agricultural Sciences and Rural Development, Nagaland University, Post Box No: 889, Nagaland,
} India

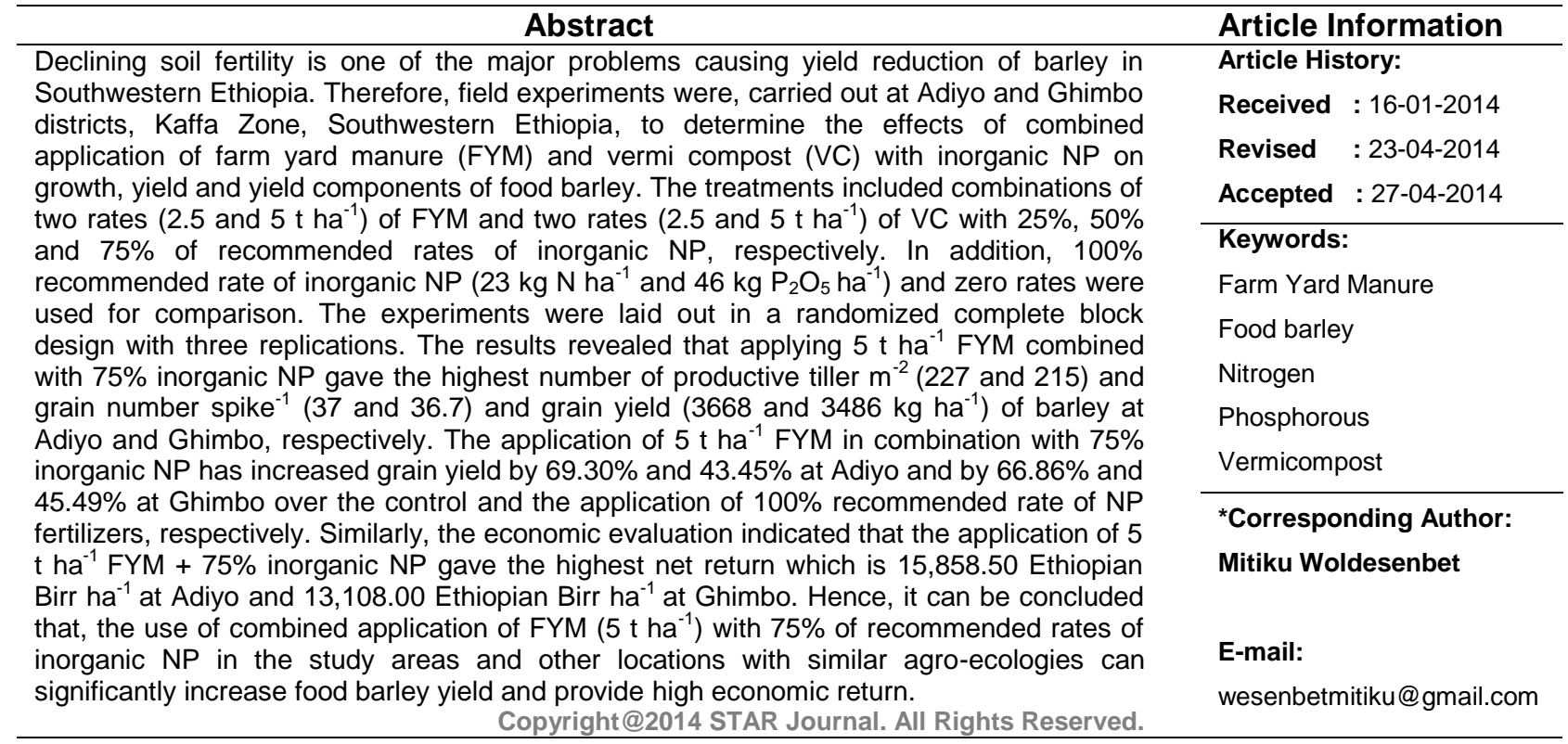

\section{INTRODUCTION}

Food barley (Hordeum vulgare L.), belonging to Poaceae family, is one of the most important staple food crops in the world. It is a cool season, most dependable and early maturing cereal crop with relatively high yielding potential in diverse agro-ecologies including marginal areas where other cereal crops are not adapted (Martin et al., 2006). Barley can be cultivated at altitudes between 1500 and 3500 m.a.s.I but it is predominantly grown between altitudes of 2000 to 3000 m.a.s.I in Ethiopia (Berhane et al., 1996). Barley cultivation and its use in Ethiopia is unique in that in no other country the crop is grown in environments so diverse in terms of altitude, rainfall, soil and farming systems.

Barley grain consists of mainly carbohydrates, proteins, and lipids. The grain is used locally for the preparation of different food stuffs such as injera, porridge, kolo, and local drinks such as tela, and borde in Ethiopia. The straw is used as animal feed especially during dry season. It is also useful for thatching roofs and as bedding materials. In Kaffa Zone of Southwestern Ethiopia, barley is one of the major and widely cultivated small cereal crops. Nationally, it covers 1,018,752.94 ha of land with the production of 1,781,652.208 t. In Kaffa Zone alone, barley covers $10,027.76$ ha and $13,305.79 \mathrm{t}$ in production (CSA, 2013). However, this yield is far lower than the world average (145.12 million $\mathrm{t}$ ) according to (FAO, 2013) mainly due to declining soil fertility.

One of the contributing factors to low yield generally in Ethiopia and particularly in the study areas was the inadequate agronomic management practices specifically, inadequate and inappropriate application of fertilizer and manure by barley growers. Barley is a gross feeder crop, requiring large quantities of fertilizers. However, intensive use of only chemical fertilizers without supplementing organic sources and the high cost of chemical fertilizers which are not affordable by the small holder farmers in the study areas accompanied by high amount of rainfall that might have caused leaching of macro- and micro-nutrients 


\section{Mitiku Woldesenbet et al.,}

create a number of problems which have significantly reduced soil fertility and crop productivity (Personal Communication)

Continuous uses of inorganic fertilizers lead to deterioration of soil chemical and physical properties, biological activities and thus in general the total soil health (Mahajan et al., 2008). Nutrients supplied exclusively through chemical sources, though enhance yield initially, lead to unsustainable productivity over the years (Satyanarayana et al., 2002; Mahajan et al., 2008). Thus the negative impacts of chemical fertilizers, coupled with their high prices, have prompted the interest in the use of organic fertilizers as source of nutrients. Organic fertilizer application has been reported to improve crop growth by supplying plant nutrients including micro-nutrients as well as improving soil physical, chemical, and biological properties thereby provide a better environment for root development by improving the soil structure (Dejene and Lemlem, 2012).

So far, many research findings have shown that neither inorganic fertilizers nor organic sources alone can result in sustainable productivity (Satyanarayana et al., 2002; Godara et al., 2012). Furthermore, the price of inorganic fertilizers is increasing and becoming unaffordable for resource-poor smallholder farmers. The best remedy for soil fertility management is, therefore, a combination of both inorganic and organic fertilizers, where the inorganic fertilizer provides readily available nutrients and the organic fertilizer mainly increases soil organic matter and improves soil structure and buffering capacity of the soil (Godara et al., 2012). The combined application of inorganic and organic fertilizers, usually termed as integrated nutrient management, is widely recognized as a way of increasing yield and or improving productivity of the soil sustainably (Mahajan et al., 2008). Several researchers (Singh and Agrawal, 2001; Mahajan et al., 2008; Getachew, 2009; Gafar et al., 2012) have demonstrated the beneficial effect of integrated nutrient management in mitigating the deficiency of several macro- and micro-nutrients. In view of this fact, identifying the optimum dose of integrated nutrients application is crucial and is required for maintaining adequate supply of nutrients for increased yield.

However, research on integrated nutrient management for barley production has not been yet conducted in Kaffa Zone, Southwestern Ethiopia. This study was, therefore, conducted to determine the effect of the combined application of FYM and VC with inorganic NP fertilizers on the growth, yield and yield components of food barley and to determine appropriate rates of combined FYM and VC with inorganic NP fertilizers for improved productivity of the crop.

\section{MATERIALS AND METHODS}

\section{Description of the Study Site}

The experiment was conducted in two districts namely, Ghimbo and Adiyo of Kaffa Zone, Southwestern Ethiopia, during 2013 main cropping season. Ghimbo and Adiyo districts are located at $8^{\circ} 06^{\prime} \mathrm{N}, 36^{\circ} 28^{\prime} \mathrm{E}, 2002$ m.a.s.I. and $9^{\circ} 05^{\prime} \mathrm{N}, 42^{\circ} 33^{\prime} \mathrm{E}, 2350$ m.a.s.l., respectively. The rainfall pattern of these areas is characterized by bimodal distribution with small rainy season belg (March-June) and main rainy seasons Meher (July-November) (Banti, 2009). The annual total rainfall was $1120 \mathrm{~mm}$ at Ghimbo and
Sci. Technol. Arts Res. J., April-June 2014, 3(2): 34-42

$1367 \mathrm{~mm}$ at Adiyo with respective mean annual temperature of 14.7 and $19.7^{\circ} \mathrm{C}$.

The soil physico chemical analysis of the study areas revealed that the soils of the experimental field were clay loam and clay in texture at Adiyo and Ghimbo, respectively. The results also indicated that the soil of Adiyo and Ghimbo are slightly acidic with $\mathrm{pH}$ of 6.03 and 5.70 , respectively. The soils have medium organic carbon and total $\mathrm{N}(\%)$ at Adiyo and low organic carbon and total $\mathrm{N}(\%)$ at Ghimbo. Available P (ppm) is low both at Adiyo and Ghimbo (Table 2).

Table 1: Organic matter, N, P, K \& moisture composition of the FYM and VC used in the experiment.

\begin{tabular}{lcc}
\hline \multicolumn{1}{c}{ Parameter } & FYM & Vermi compost \\
\hline Organic matter (\%) & 9.77 & 5.56 \\
Total N (\%) & 1.77 & 1.26 \\
Available P (\%) & 0.62 & 0.41 \\
Available K (\%) & 2.55 & 2.24 \\
Moisture content (\%) & 20 & 14 \\
\hline
\end{tabular}

\section{Treatments and Experimental Design}

The treatments consisted of combinations of two rates of FYM (2.5 and $\left.5 \mathrm{tha}^{-1}\right)$ and two rates of VC $(2.5$ and $5 \mathrm{t}$ $\left.\mathrm{ha}^{-1}\right)$ with three recommended rates $(25,50$ and $75 \%)$ of inorganic NP fertilizers. In addition, $100 \%$ recommended rate of inorganic NP fertilizer $\left(23 \mathrm{~kg} \mathrm{~N}\right.$ and $46 \mathrm{~kg} \mathrm{P}_{2} \mathrm{O}_{5}$ ) and zero rates were used for comparison. Thus there were 14 treatments. The experiment was laid out in a randomized complete block design with three replications. The gross and net plot sizes were $2.4 \mathrm{~m} \times 3 \mathrm{~m}$ and $1.6 \mathrm{~m}$ $\times 2.6 \mathrm{~m}$, respectively. A food barley variety called 'GABULA' was used as a test crop. The variety was released in 2007 by Hawassa Agricultural Research Center, Ethiopia, for its high yield and promising agronomic performances in the study areas. The variety matures in 95 days and has an average height of $100 \mathrm{~cm}$ (MoARD, 2007).

\section{Experimental Procedures}

Farm yard manure (FYM) was applied on dry weight basis three weeks prior to planting and thoroughly mixed with the soil in the field. Well decomposed vermi compost (VC) was applied during planting time on treatment basis. The organic carbon, $\mathrm{N}, \mathrm{P}, \mathrm{K}$ and moisture contents of the FYM and VC used in the experiments were determined. All $P$ and half of the $N$ fertilizer sources for the respective inorganic NP treatments were applied at planting. The remaining half of the inorganic $\mathrm{N}$ fertilizer was applied at tillering stage by side drilling.

Prior to planting, surface $(0-30 \mathrm{~cm})$ soil samples, from five spots across the experimental fields, were collected in a zigzag pattern, composited, and analyzed for soil physico-chemical properties and the results are depicted in Table 2.

Soil texture was determined using Bouyoucos hydrometer method (Bouyoucous, 1951); soil $\mathrm{pH}$ at 1:2.5 soils to water ratio by $\mathrm{pH}$ digital meter (Page, 1982); soil organic carbon by wet digestion method (Walkley and Black, 1954) and total $\mathrm{N}$ by Kjeldhal method (Jackson 1973). Available phosphorus was determined by the Olsen method (Olsen et al., 1954); the cation exchange capacity (CEC) using 1M-neutral ammonium acetate (Jackson, 1973). 
Mitiku Woldesenbet et al.,

Table 2: Physico-chemical characteristics of soil of the experimental sites

\begin{tabular}{lcc}
\hline \multirow{2}{*}{ Soil parameters } & \multicolumn{2}{c}{ Districts } \\
\cline { 2 - 3 } & Ghimbo & Adiyo \\
\hline Textural composition (\%) & & \\
Sand & 18.0 & 17.9 \\
Silt & 21.0 & 26.9 \\
Clay & 61.0 & 55.2 \\
\hline Textural class & Clay & Clay loam \\
pH & 5.70 & 6.03 \\
Organic Carbon (\%) & 1.30 & 1.52 \\
Total N (\%) & 0.08 & 0.11 \\
Available P $\left(\mathrm{mg} \mathrm{kg}^{-1}\right)$ & 6.70 & 7.10 \\
CEC $(\mathrm{cmol} / \mathrm{kg})$ & 20.15 & 18.05 \\
\hline
\end{tabular}

The barley seeds were planted in rows spaced $20 \mathrm{~cm}$ apart by hand drilling at the seed rate of $120 \mathrm{~kg} \mathrm{ha}^{-1}$. Weeds were removed manually three times (i.e. at early tillering, maximum tillering and booting stages). No insecticide or fungicide was applied as there was no serious incidence of insect pests or diseases. Harvesting was done manually using hand sickles. The harvested product was sun-dried for 8 days and threshing and winnowing were done subsequently.

\section{Data Collection}

Days to heading were recorded when the ears or panicles were fully visible on $50 \%$ of the plants from each plot by visual observation and days to physiological maturity were recorded when $90 \%$ of the plants reached maturity in each plot, i.e. when grains were difficult to divide by thumb nail. Number of productive tillers $\mathrm{m}^{-2}$ was counted from two random $1 \mathrm{~m} \times 1 \mathrm{~m}$ areas (5 rows of $1 \mathrm{~m}$ length) within the net plot area at physiological maturity and the average was recorded as number of productive tiller $\mathrm{m}^{-2}$. Plant height $(\mathrm{cm})$ was determined from measurements of 10 randomly pre-tagged mother shoots from ground level to the top of the spike excluding the awns at physiological maturity. Likewise, the spikes in the pre-tagged 10 plants were collected and the total grains were counted to record the number of grains per spike. Thousand grains were counted in each plot using electronic seed counter from a bulk of threshed grain and their weight was measured using a sensitive balance at harvest and the weight was adjusted to $12.5 \%$ moisture content.

The total aboveground dry biomass yield including straw and spikes of plants in a net plot area was measured using spring balance after sun drying to a constant weight. Then threshed and the grain yield per net plot was weighed and adjusted to $12.5 \%$ moisture content. Harvest index was calculated as the ratio of grain yield to total aboveground dry biomass and expressed in percentage.

\section{Statistical Data Analysis}

The agronomic data were subjected to analysis of variance (GLM procedure) using SAS software program version 9.2 (SAS Institute, 2003). Homogeneity of variances was evaluated using the F-test as described by Gomez and Gomez (1984) and since the F-test has showed heterogeneity of the variances of the two locations for most of the agronomic parameters, separate analysis was used for the two locations. The Fisher's
Sci. Technol. Arts Res. J., April-June 2014, 3(2): 34-42

protected least significant difference (LSD) test at 0.05 probability level was employed to separate treatment means where significant treatment differences existed.

\section{Partial Budget Analysis}

The partial budget analysis as described by CIMMYT (1988) was done to determine the economic feasibility of the fertilizer application. It was calculated by taking into account the additional input cost (variable cost) involved and the gross returns obtained from different treatments. The variable cost also included the labor cost involved for harvesting, threshing and winnowing of the produce as this varied according to the yield obtained from a particular treatment. For determining gross returns, the prevailing local market price at the harvest of barley (5.50 and 5.00 Ethiopian Birr $\mathrm{kg}^{-1}$, at Adiyo and Ghimbo, respectively) was used for computation. The net returns were calculated by subtracting the cost of treatment from its gross returns, i.e. RNR = GR-VC where, RNR = Relative net returns, $\mathrm{GR}=$ Gross returns, and $\mathrm{VC}=$ Variable cost.

\section{RESULTS AND DISCUSSION}

\section{Phenological and Growth Parameters}

There was no significant difference in the number of days to heading and maturity due to the application of different rates of VC and FYM in combination with varied rates of inorganic NP both at Adiyo and Ghimbo (data not shown). However, the application of fertilizers of any source, irrespective of their doses hastened days to heading and maturity as compared to no fertilizer application.

On the other hand, there was significant $(P<0.05)$ effect of combined application of organic and inorganic fertilizers on plant height. Results showed that all the treatments increased plant height over the control (Table 3 ). The tallest plants were obtained at the rate of $5 \mathrm{t} \mathrm{ha}^{-1}$ FYM $+75 \%$ of recommended NP at Adiyo and from the application of $5 \mathrm{t} \mathrm{ha}^{-1} \mathrm{VC}+75 \%$ recommended inorganic NP at Ghimbo. However, the shortest plants were from the control both at Adiyo and Ghimbo. It was observed from both Adiyo and Ghimbo that plant height increased when organic fertilizer sources were combined with increased rate $(75 \%)$ of inorganic NP in most plots.

The possible reason for maximum height in FYM or VC plus mineral NP treatment might be that the mineral NP sources fulfilled the NP requirements at early growth stages while farmyard manure and vermicompost provided the crop with maximum nutrients in later stages. Thus, combination of (FYM + inorganic NP and VC + inorganic NP) might have nourished the crop in initial stages as well as in the later growth stages. The result of this experiment agreed with the finding of Amanuliah and Maimoona (2007) who reported that the use of increased rates of $\mathrm{FYM}$ and $\mathrm{N}$ increased plant height of wheat and the shortest plants recorded from the control treatment. Also in agreement with this result, Ofosu and Leitch (2009) reported that plant height of spring barley increased with organic manure application as compared to inorganic fertilizer alone. Similarly, Getachew (2009) reported that the use of organic manures in combination with mineral fertilizers maximized the plant height than the application of inorganic fertilizers alone. 
Mitiku Woldesenbet et al.,

\section{Yield Components}

It was observed that the combined application of organic and inorganic fertilizers also increased the number of productive tillers $\mathrm{m}^{-2}$ both at Adiyo and Ghimbo. As a result, the application of $5 \mathrm{t} \mathrm{ha}^{-1} \mathrm{FYM}$ with $75 \%$ inorganic NP resulted in the highest number (227) and (215) of productive tillers $\mathrm{m}^{-2}$ at Adiyo and Ghimbo,
Sci. Technol. Arts Res. J., April-June 2014, 3(2): 34-42

respectively. This treatment gave $65.63 \%$ and $66.83 \%$ increase over the control treatment at Adiyo and Ghimbo, respectively (Table 3 ). This might be due to the increased rate of FYM which might have attributed to the increased availability of NPK, improvement of soil water holding capacity and reduction of volatilization of nitrogenous fertilizer to $\mathrm{NH}_{3}$ gas.

Table 3: Plant height $(\mathrm{cm})$, number of productive tillers $\mathrm{m}^{-2}$ and number of grains spike ${ }^{-1}$ of barley as influenced by integrated nutrient management at Adiyo and Ghimbo, Southwestern Ethiopia

\begin{tabular}{|c|c|c|c|c|c|c|}
\hline \multirow[t]{2}{*}{ Treatment $^{*}$} & \multirow[b]{2}{*}{$\begin{array}{l}\text { Plant } \\
\text { height }\end{array}$} & \multicolumn{2}{|c|}{ Adiyo } & \multicolumn{3}{|c|}{ Ghimbo } \\
\hline & & $\begin{array}{l}\text { Number } \\
\text { of tillers }\end{array}$ & $\begin{array}{l}\text { Number } \\
\text { of grains }\end{array}$ & $\begin{array}{l}\text { Plant } \\
\text { height }\end{array}$ & $\begin{array}{l}\text { Number } \\
\text { of tillers }\end{array}$ & $\begin{array}{l}\text { Number } \\
\text { of grains }\end{array}$ \\
\hline 2.5 t ha $^{-1} \mathrm{VC}+25 \% \mathrm{RDF}$ & $95.1^{\text {gh }}$ & $158.0^{\mathrm{de}}$ & $28.0^{\mathrm{ef}}$ & $95.0^{\mathrm{fg}}$ & $144.0^{\mathrm{ef}}$ & $27.3^{\mathrm{de}}$ \\
\hline $2.5 \mathrm{t} \mathrm{ha}^{-1} \mathrm{VC}+50 \% \mathrm{RDF}$ & $97.3^{\mathrm{fgh}}$ & $162.0^{d}$ & $29.0^{\operatorname{def}}$ & $98.1^{\mathrm{e}}$ & $153.0^{\mathrm{de}}$ & $26.0^{\mathrm{de}}$ \\
\hline 2.5 t ha $^{-1} \mathrm{VC}+75 \%$ RDF & $101.8^{\mathrm{bcd}}$ & $178.0^{\mathrm{C}}$ & $31.0^{\mathrm{b}-\mathrm{e}}$ & $102.3^{\mathrm{abcd}}$ & $165.0^{\mathrm{cd}}$ & $27.3^{\text {de }}$ \\
\hline $2.5 \mathrm{t} \mathrm{ha}^{-1} \mathrm{FYM}+25 \%$ RDF & $96.0^{g h}$ & $164.0^{\mathrm{d}}$ & $29.0^{\text {def }}$ & $97.6^{\mathrm{ef}}$ & $149.0^{\text {ef }}$ & $28.0^{\mathrm{cd}}$ \\
\hline $2.5 \mathrm{t} \mathrm{ha}^{-1} \mathrm{FYM}+50 \%$ RDF & $100.6^{\text {cde }}$ & $191.0^{c}$ & $33.0^{a-e}$ & $101.0^{\mathrm{bcd}}$ & $173.0^{c}$ & $33.0^{\mathrm{ab}}$ \\
\hline $2.5 \mathrm{t} \mathrm{ha}^{-1} \mathrm{FYM}+75 \%$ RDF & $103.0^{\mathrm{abc}}$ & $206.0^{\mathrm{b}}$ & $36.3^{\mathrm{ab}}$ & $103.6^{\mathrm{ab}}$ & $187.3^{\mathrm{b}}$ & $36.3^{a}$ \\
\hline 5 t ha $^{-1}$ VC+25\% RDF & $97.6^{\text {efg }}$ & $178.0^{\mathrm{C}}$ & $33.0^{\mathrm{a}-\mathrm{e}}$ & $100.3^{\text {cde }}$ & $157.0^{\mathrm{de}}$ & $29.6^{\mathrm{bcd}}$ \\
\hline 5 t ha $^{-1}$ VC+50\% RDF & $101.6^{\mathrm{bcd}}$ & $186.0^{\mathrm{C}}$ & $30.7^{\text {cde }}$ & $101.6^{\mathrm{abcd}}$ & $174.0^{\mathrm{bc}}$ & $32.6^{\mathrm{abc}}$ \\
\hline 5 t ha $^{-1}$ VC+75\% RDF & $104.0^{\mathrm{ab}}$ & $188.0^{\mathrm{C}}$ & $34.0^{\mathrm{a}-\mathrm{d}}$ & $104.3^{\mathrm{a}}$ & $178.0^{\mathrm{bc}}$ & $29.6^{\mathrm{bcd}}$ \\
\hline 5 t ha $^{-1}$ FYM+25\% RDF & $101.3^{\mathrm{bcd}}$ & $211.3 .0^{b}$ & $34.1^{a-d}$ & $99.6^{\text {de }}$ & $209.0^{\mathrm{a}}$ & $34.3^{\mathrm{ab}}$ \\
\hline $5 \mathrm{t} \mathrm{ha}^{-1} \mathrm{FYM}+50 \%$ RDF & $104.0^{\mathrm{ab}}$ & $218.0^{\mathrm{ab}}$ & $36.0^{\mathrm{abc}}$ & $101.6^{\mathrm{abcd}}$ & $207.0^{\mathrm{a}}$ & $36.3^{\mathrm{a}}$ \\
\hline 5 t ha $^{-1}$ FYM+75\% RDF & $105.3^{\mathrm{a}}$ & $227.0^{\mathrm{a}}$ & $37.0^{\mathrm{a}}$ & $103.0^{\mathrm{abc}}$ & $215.0^{\mathrm{a}}$ & $36.7^{\mathrm{a}}$ \\
\hline $100 \%$ RDF & $99.6^{\text {def }}$ & $145.0^{\mathrm{e}}$ & $37.0^{a-d}$ & $99.6^{\mathrm{de}}$ & $137.0^{f}$ & $34.3^{\mathrm{ab}}$ \\
\hline Control & $94.3^{\mathrm{h}}$ & $78.0^{f}$ & $26.0^{\text {def }}$ & $94.4^{\mathrm{g}}$ & $71.3^{f}$ & $23.3^{\mathrm{e}}$ \\
\hline LSD (5\%) & 3.03 & 13.99 & 5.565 & 2.73 & 14.18 & 4.92 \\
\hline CV $(\%)$ & 1.63 & 4.70 & 10.62 & 1.45 & 5.11 & 8.20 \\
\hline
\end{tabular}

Means followed by the same letter within a column are not significantly different to each other at $5 \%$ level of significance ${ }^{*} \mathrm{FYM}=$ Farm Yard Manure, RDF = Recommended Dose of inorganic NP Fertilizer, VC = Vermi Compost

It was also observed that as rate of inorganic NP increased from 25 to $75 \%$, there was increase in number of productive tillers $\mathrm{m}^{-2}$ both at Adiyo and Ghimbo. The increased number of productive tillers $\mathrm{m}^{-2}$ at higher NP rates might be due to vigorous growth and development of the crop because the nutrients applied from inorganic sources coupled with organic sources might have attributed to more availability of $\mathrm{N}$ that played a vital role in cell division. Similarly, Fageria (2009) reported that rice tillering was minimized in the plot that did not receive $P$ fertilization compared to the plot that received $N$ and $P$ fertilizers in upland rice. The favorable effects of NP might have led to the production of more number of productive tillers $\mathrm{m}^{-2}$ at higher levels of NP (lqtidar et al., 2006).

At later crop growth stages, however, the mineralization of FYM and VC coupled with increased doses of inorganic NP might have contributed to the increased number of productive tillers $\mathrm{m}^{-2}$ over the control. The mineralization of FYM and VC gradually releases essential nutrients over a period than the applied inorganic NP, hence reducing their leaching and improving the efficiency of their uptake on account of reduction in synchrony time of the crop nutrient demand and manures nutrient release contributed to the increased number of productive tillers $\mathrm{m}^{-2}$.

Similar to the effect on number of productive tillers $\mathrm{m}^{-2}$, the application of $5 \mathrm{t} \mathrm{ha}^{-1} \mathrm{FYM}$ in combination with $75 \%$ of inorganic NP fertilizer resulted in the highest number of grains spike ${ }^{-1}$ both at Adiyo (37.00) and Ghimbo (36.7) showing an advantage of $29.72 \%$ at Adiyo and $36.51 \%$ at Ghimbo, respectively, over the control (Table 3). The possible reason for the increased number of grains spike ${ }^{-1}$ could be that mineral fertilizer and mineralization of organic fertilizer sources throughout the growing period did not put the plants in nutrient stress at any stage resulting in maximum grain production. In agreement with these results, several workers (Singh and Agarwal 2001; lqbal et al. 2002; Arif et al. 2006) have reported significant increase in the number of grains spike ${ }^{-1}$ of wheat by applying organic manures and mineral fertilizer in combination as compared to inorganic fertilizer application alone.

The highest thousand grain weight $(45.00 \mathrm{~g})$ was obtained when $5 \mathrm{t} \mathrm{ha}^{-1}$ FYM was applied in combination with $25 \%$ recommended rate of inorganic NP at Ghimbo while at Adiyo the highest thousand grain weight $(44.33 \mathrm{~g})$ was obtained due to the application of $5 \mathrm{t} \mathrm{ha}^{-1} \mathrm{FYM}$ in combination with $75 \%$ recommended rate of inorganic NP. In agreement to this result, Mehta (2005) reported significantly higher wheat thousand grain weight with FYM $\left(2.5 \mathrm{t} \mathrm{ha}^{-1}\right)+$ Leucaena biomass $\left(2.5 \mathrm{t} \mathrm{ha}^{-1}\right)+75 \%$ RDF than $100 \%$ recommended rate of inorganic NP fertilizer and attributed this to better availability of nutrients. In contrast to this result, Oo et al. (2010) reported nonsignificant effect of organic fertilizers on thousand grain weight of rice.

The lowest thousand grain weights $36.00 \mathrm{~g}$ at Ghimbo and $35.67 \mathrm{~g}$ at Adiyo were recorded from the control plots. 


\section{Mitiku Woldesenbet et al.,}

This decrease in thousand grain weights could be due to shrivelled seeds that have less size which contributed to the less thousand grain weight. These results were in agreement with Rasool et al. (2008) who reported that thousand grain weight of wheat was significantly increased with the use of recommended dose of inorganic NPK in combination with FYM. Similarly, Saidu et al. (2012) also obtained the highest 1000 wheat grain weight, from application of $5 \mathrm{t} \mathrm{ha}^{-1} \mathrm{FYM}$ in combination with $50 \%$ inorganic NP while the lowest 1000 grain weight was recorded from no fertilizer application.
Sci. Technol. Arts Res. J., April-June 2014, 3(2): 34-42

From this experiment it was observed that the application of $100 \%$ recommended rate of inorganic NP resulted in lower thousand grain weights both at Adiyo and Ghimbo compared to the combined application of organic and inorganic fertilizers in most treatments (Table 4). This could be due to the fact that $100 \%$ recommended rate of inorganic NP was not sufficient during grain filling of crop so that the grain with small size were harvested and resulted to lower thousand grain weight.

Table 4: Thousand grain weight and grain yield of barley as influenced by integrated nutrient management at Adiyo and Ghimbo, Southwestern Ethiopia

\begin{tabular}{|c|c|c|c|c|}
\hline \multirow[b]{2}{*}{ Treatment } & \multicolumn{2}{|c|}{ Adiyo } & \multicolumn{2}{|c|}{ Ghimbo } \\
\hline & TGW (g) & $\begin{array}{l}\text { Grain yield } \\
\left(\mathrm{kg} \mathrm{ha}^{-1}\right)\end{array}$ & TGW (g) & $\begin{array}{l}\text { Grain yield } \\
\left(\mathrm{kg} \mathrm{ha}^{-1}\right)\end{array}$ \\
\hline 2.5 t ha $^{-1} \mathrm{VC}+25 \%$ RDF & $37.00^{\mathrm{tg}}$ & $1796.3^{\text {h }}$ & $36.33^{\dagger}$ & $1525.7^{9}$ \\
\hline $2.5 \mathrm{t} \mathrm{ha}^{-1} \mathrm{VC}+50 \%$ RDF & $40.33^{\text {bcde }}$ & $1912.0^{\operatorname{tgn}}$ & $36.50^{\text {et }}$ & $1756.3^{\text {etg }}$ \\
\hline $2.5 \mathrm{t} \mathrm{ha}^{-1} \mathrm{VC}+75 \%$ RDF & $39.67^{\text {cdet }}$ & $2215.0^{\text {et }}$ & $38.00^{\mathrm{de}}$ & $1973.3^{e}$ \\
\hline 2.5 tha $^{-1}$ FYM+25\% RDF & $38.33^{\text {etg }}$ & $1860.0^{\mathrm{gh}}$ & $38.33^{\mathrm{de}}$ & $1640.3^{\text {tg }}$ \\
\hline 2.5 tha $^{-1} \mathrm{FYM}+50 \%$ RDF & $42.33^{\mathrm{abcd}}$ & $2578.3^{\mathrm{cd}}$ & $42.00^{\mathrm{bc}}$ & $2365.7^{\mathrm{cd}}$ \\
\hline 2.5 tha $^{-1} \mathrm{FYM}+75 \%$ RDF & $43.67^{\mathrm{ab}}$ & $3132.0^{\mathrm{b}}$ & $44.66^{a}$ & $3026.7^{\mathrm{b}}$ \\
\hline $5 \mathrm{t} \mathrm{ha}^{-1} \mathrm{VC}+25 \% \mathrm{RDF}$ & $41.33^{\mathrm{abcde}}$ & $2280.3^{\text {de }}$ & $40.00^{c d}$ & $2066.0^{\text {de }}$ \\
\hline $5 \mathrm{t} \mathrm{ha}^{-1} \mathrm{VC}+50 \%$ RDF & $39.67^{\text {cde }}$ & $2171.7^{\text {etg }}$ & $40.00^{\mathrm{cd}}$ & $2343.7^{\mathrm{cd}}$ \\
\hline $5 \mathrm{t} \mathrm{ha}^{-1} \mathrm{VC}+75 \%$ RDF & $41.00^{\mathrm{abcd}}$ & $2568.0^{\mathrm{cd}}$ & $41.00^{c}$ & $2050.3^{\text {de }}$ \\
\hline 5 tha $^{-1} \mathrm{FYM}+25 \%$ RDF & $43.33^{\mathrm{abc}}$ & $2755.3^{c}$ & $45.00^{\mathrm{a}}$ & $2573.7^{c}$ \\
\hline 5 tha $^{-1} \mathrm{FYM}+50 \%$ RDF & $43.67^{\mathrm{ab}}$ & $3349.7^{\mathrm{b}}$ & $44.33^{\mathrm{ab}}$ & $3293.0^{\mathrm{ab}}$ \\
\hline 5 tha $^{-1} \mathrm{FYM}+75 \%$ RDF & $44.33^{\mathrm{a}}$ & $3668.0^{\mathrm{a}}$ & $43.67^{\mathrm{ab}}$ & $3486.0^{\mathrm{a}}$ \\
\hline $100 \%$ RDF & $39.00^{\text {detg }}$ & $2074.0^{\text {etgn }}$ & $40.33^{\mathrm{cd}}$ & $1900.0^{\text {et }}$ \\
\hline Control & $35.67^{g}$ & $1126.0^{\prime}$ & $36.00^{\text {et }}$ & $1155.0^{\mathrm{n}}$ \\
\hline LSD (5 \%) & 3.96 & 317.14 & 2.56 & 320.68 \\
\hline CV (\%) & 6.11 & 6.86 & 3.67 & 7.67 \\
\hline
\end{tabular}

\section{Grain Yield, above Ground Dry Biomass Yield and Harvest Index}

There was highly significant $(P<0.001)$ effect of combined application of organic and inorganic fertilizers on grain yield both at Adiyo and Ghimbo. The highest grain yields of $3668.00 \mathrm{~kg} \mathrm{ha}^{-1}$ and $3486.00 \mathrm{~kg} \mathrm{ha}^{-1}$ at Adiyo and Ghimbo, respectively, were obtained from the application of $5 \mathrm{t} \mathrm{ha}{ }^{-1}$ FYM combined with $75 \%$ recommended inorganic NP (Table 4). These were followed by the application of $5 \mathrm{t} \mathrm{ha}^{-1}$ FYM with $50 \%$ recommended rate of inorganic NP.

This indicates that the application of $5 \mathrm{t} \mathrm{ha}^{-1} \mathrm{FYM}+$ $75 \%$ inorganic NP were optimum for the maximum productivity of barley crop in the study areas and more than this rate might cause yield decreases. Similarly, Singh et al. (1995) reported that increasing NP beyond the optimum requirement level of the crop resulted in decline of grain yield in rice. The maximum grain yields obtained from the combined application of $5 \mathrm{tha}^{-1} \mathrm{FYM}$ with $75 \%$ recommended rate of inorganic NP had an advantage of $43.45 \%$ over the application of $100 \%$ recommended rate of inorganic NP at Adiyo and $45.49 \%$ at Ghimbo, respectively.

The increase in yield of barley due to the integration of FYM with $75 \%$ inorganic fertilizers over $100 \%$ of inorganic NP might be due to the addition of nutrients from the
FYM, which indicates that even full rate of inorganic NP was not adequate for barley production both at Adiyo and Ghimbo and additional fertilizers are required. This result was in agreement with the finding of Abay and Tesfaye (2012) who reported that the application of inorganic fertilizers (NP or NPK) with FYM gave a better yield of barley than the application of $100 \%$ inorganic fertilizers alone. This indicates that application of FYM is more important than the application of inorganic fertilizers alone which might be attributed to the beneficial effects of FYM on the soil's physical, chemical and microbiological properties (Chong, 2005). The increased yield due to the application of $5 \mathrm{t} \mathrm{ha}^{-1} \mathrm{FYM}$ with the combination of $75 \%$ of inorganic NP in these areas on the other hand could be due to the balanced supply of essential nutrients from their integration.

The present trend of increase in yield with the combined application of organic and inorganic fertilizers over the control was in conformity with the findings of Parihar et al. (2010) who reported that the combined application of FYM and inorganic NPK fertilizers increased the yield of pearl millet crop by improving the physical and chemical properties of the soil.

Though the application of VC did not perform better than FYM with respect to yield and yield components of barley in this experiment, the report of Ranva and Singh 


\section{Mitiku Woldesenbet et al.,}

(2006) indicated that VC in wheat resulted in a significant increase in all of the growth parameters and yield attributes than the application of FYM. The low performance of $\mathrm{VC}$ in this study could be the low organic matter and NPK content of VC compared with FYM. On the other hand, the source from which VC was made may not be as nutritious as FYM as well as the acidic soil of the study area might not be comfortable for the decomposition of VC. Similarly Yavarzadeh and Shamsadini (2012) reported that the effectiveness of VC fertilizer depends on the resources from which it was made and its decomposition and productivity is more efficient in neutral soil $\mathrm{pH}$ condition.
Sci. Technol. Arts Res. J., April-June 2014, 3(2): 34-42

Above ground biomass yield was significantly $(P<0.05)$ influenced due to the combined application of organic and inorganic fertilizers both at Adiyo and Ghimbo. Accordingly, the application of $5 \mathrm{t} \mathrm{ha}^{-1} \mathrm{FYM}$ in combination with $75 \%$ inorganic NP gave the highest biomass yield of 8259.3 and $8065.0 \mathrm{~kg} \mathrm{ha}^{-1}$ at Adiyo and Ghimbo, respectively (Table 5). This was followed by $5 \mathrm{t} \mathrm{ha}^{-1} \mathrm{VC}+$ $75 \%$ inorganic NP with biomass yield of $7564.0 \mathrm{~kg} \mathrm{ha}^{-1}$ at Adiyo and $5 \mathrm{t} \mathrm{ha}^{-1} \mathrm{FYM}+50 \%$ inorganic NP with biomass yield of $7381.0 \mathrm{~kg} \mathrm{ha}^{-1}$ at Ghimbo. The possible reasons for the difference results at the two locations from different treatments could be the difference in the initial soil constituents and agro-ecologies.

Table 5: Above ground dry biomass yield and harvest index of barley as influenced by integrated nutrient management at Adiyo and Ghimbo, Southwestern Ethiopia

\begin{tabular}{|c|c|c|c|c|}
\hline \multirow[b]{2}{*}{ Treatment } & \multicolumn{2}{|c|}{ Adiyo } & \multicolumn{2}{|c|}{ Ghimbo } \\
\hline & $\begin{array}{c}\text { AGDB Yield } \\
\left(\mathrm{kg} \mathrm{ha}^{-1}\right)\end{array}$ & $\begin{array}{c}\text { Harvest Index } \\
(\%)\end{array}$ & $\begin{array}{c}\text { AGDB Yield } \\
\left(\mathrm{kg} \mathrm{ha}^{-1}\right)\end{array}$ & $\begin{array}{c}\text { Harvest Index } \\
(\%)\end{array}$ \\
\hline $2.5 \mathrm{t} \mathrm{ha}^{-1} \mathrm{VC}+25 \%$ RDF & $4337.3^{i}$ & $41.43^{\mathrm{bc}}$ & $3825.3^{i}$ & $39.87^{\mathrm{a}}$ \\
\hline $2.5 \mathrm{t} \mathrm{ha}^{-1} \mathrm{VC}+50 \%$ RDF & $4821.3^{\mathrm{hl}}$ & $39.65^{\mathrm{cd}}$ & $4268.7^{\mathrm{hl}}$ & $41.30^{\mathrm{a}}$ \\
\hline $2.5 \mathrm{t} \mathrm{ha}^{-1} \mathrm{VC}+75 \% \mathrm{RDF}$ & $7049.7^{\mathrm{cd}}$ & $31.40^{\mathrm{e}}$ & $6914.7^{\mathrm{bc}}$ & $29.08^{b}$ \\
\hline 2.5 tha $^{-1} \mathrm{FYM}+25 \%$ RDF & $5752.3^{\mathrm{g}}$ & $32.39^{e}$ & $5646.7^{\mathrm{et}}$ & $28.53^{\mathrm{b}}$ \\
\hline 2.5 tha $^{-1} \mathrm{FYM}+50 \%$ RDF & $6173.3^{\text {tg }}$ & $41.86^{\mathrm{abc}}$ & $5796.0^{\mathrm{ef}}$ & $41.00^{\mathrm{a}}$ \\
\hline 2.5 tha $^{-1} \mathrm{FYM}+75 \%$ RDF & $6775.3^{\text {cde }}$ & $46.22^{\mathrm{ab}}$ & $7261.0^{\mathrm{bc}}$ & $41.76^{\mathrm{a}}$ \\
\hline $5 \mathrm{t} \mathrm{ha}^{-1} \mathrm{VC}+25 \% \mathrm{RDF}$ & $6581.7^{\text {det }}$ & $34.83^{\mathrm{de}}$ & $6666.0^{\mathrm{cd}}$ & $31.01^{\mathrm{b}}$ \\
\hline $5 \mathrm{t} \mathrm{ha}^{-1} \mathrm{VC}+50 \%$ RDF & $7066.3^{\mathrm{bcd}}$ & $30.79^{e}$ & $7059.0^{\mathrm{bc}}$ & $33.26^{\mathrm{b}}$ \\
\hline $5 \mathrm{t} \mathrm{ha}^{-1} \mathrm{VC}+75 \%$ RDF & $7564.0^{\mathrm{b}}$ & $33.95^{\mathrm{e}}$ & $5103.3^{\text {tg }}$ & $40.24^{\mathrm{a}}$ \\
\hline 5 tha $^{-1} \mathrm{FYM}+25 \%$ RDF & $6479.0^{\text {ef }}$ & $42.51^{\mathrm{abc}}$ & $6176.3^{\text {de }}$ & $41.85^{\mathrm{a}}$ \\
\hline 5 tha $^{-1} \mathrm{FYM}+50 \%$ RDF & $7177.0^{\mathrm{bc}}$ & $46.80^{\mathrm{a}}$ & $7381.0^{\mathrm{ab}}$ & $44.72^{\mathrm{a}}$ \\
\hline 5 tha $^{-1} \mathrm{FYM}+75 \%$ RDF & $8259.3^{a}$ & $44.42^{\mathrm{abc}}$ & $8065.0^{\mathrm{a}}$ & $43.17^{\mathrm{a}}$ \\
\hline $100 \%$ RDF & $4925.7^{\mathrm{h}}$ & $42.02^{\mathrm{abc}}$ & $4679.0^{g h}$ & $40.77^{\mathrm{a}}$ \\
\hline Control & $3525.0^{\prime}$ & $30.77^{\mathrm{e}}$ & $3677.0^{\prime}$ & $31.57^{\mathrm{b}}$ \\
\hline LSD (5\%) & 509.84 & 5.28 & 698.15 & 6.13 \\
\hline CV (\%) & 3.80 & 8.18 & 6.89 & 7.44 \\
\hline
\end{tabular}

Generally, it was observed that except the combined application of $2.5 \mathrm{t} \mathrm{ha}^{-1} \mathrm{VC}$ with 25 and $50 \%$ inorganic NP fertilizers both at Adiyo and Ghimbo, the combined application of organic and inorganic fertilizers have resulted in higher aboveground biomass yield than the application of $100 \%$ recommended rate of inorganic NP alone. This implies that integrated use of organic and inorganic fertilizers responded better to increase productivity than the use of inorganic fertilizer alone in the study areas. Likewise, Shata et al. (2007) suggested that by the use of mixed chemical and bio fertilizers not only production can be kept at optimum level, but also the amount of chemical fertilizer to be used can be reduced. Plant bio-chemical activities improve by absorption of nutrients from soil and this increase the grain yield and biological yield plant ${ }^{-1}$.

Harvest index was significantly influenced by the combined application of organic and inorganic fertilizer sources (Table 5). The highest harvest indices, i.e. $46.80 \%$ at Adiyo and $44.72 \%$ at Ghimbo were recorded by the application of $5 \mathrm{t} \mathrm{ha}^{-1} \mathrm{FYM}+50 \%$ inorganic NP. From this experiment, it was observed that the increased rate of
FYM and inorganic NP has increased the harvest index of barley both at Adiyo and Ghimbo. The possible reason could be the increased rate of FYM and inorganic NP that might have increased the efficiency of the barley to partition the dry matter to the seed. Similarly, Mooleki et al. (2004) indicated the increased rate of either FYM or inorganic NP has increased the harvest index of rice.

The result of this experiment also indicated that the lowest harvest index $(28.53 \%$ at Ghimbo and $30.79 \%$ at Adiyo) were recorded from the application of $2.5 \mathrm{t} \mathrm{ha}^{-1}$ FYM $+25 \%$ inorganic NP and from 5 t ha $^{-1} \mathrm{VC}+50 \%$ inorganic NP, respectively (Table 5). This was because of that these treatments had higher aboveground biomass yield that narrowed the gap between grain yield and aboveground biomass yield and lead to the less harvest index compared to the control plot both at Adiyo and Ghimbo.

\section{Economic Evaluation}

The economic analysis revealed that highest net returns of Birr 15,858.50 ha ${ }^{-1}$ at Adiyo and 13,108.00 at Ghimbo were obtained by the application of $5 \mathrm{t} \mathrm{ha}^{-1} \mathrm{FYM}$ 
Mitiku Woldesenbet et al.,

$+75 \%$ inorganic NP followed by $5 \mathrm{t} \mathrm{ha}^{-1} \mathrm{FYM}+50 \%$ inorganic NP which gave net return of Birr 14,197.35 ha ${ }^{-1}$ at Adiyo and 12,187.00 at Ghimbo. On the other hand, the lowest net return was received from no fertilizer application both at Adiyo and Ghimbo (Table 6 and 7). In
Sci. Technol. Arts Res. J., April-June 2014, 3(2): 34-42

line with this result, Abay and Tesfaye (2012) reported that the application of $46 \mathrm{~kg} \mathrm{~N}+40 \mathrm{~kg} \mathrm{P}+20 \mathrm{t} \mathrm{FYM} \mathrm{ha}{ }^{1}$ gave the highest net return and the lowest net return was obtained from no fertilizer application in barley.

Table 6: Partial budget analysis to estimate net benefit as influenced by integrated nutrient management on barley at Adiyo, Southwestern Ethiopia

\begin{tabular}{|c|c|c|c|c|}
\hline Treatment ${ }^{*}$ & $\begin{array}{c}\begin{array}{c}\text { Yield } \\
\left(\mathrm{kg} \mathrm{ha}^{-1}\right)\end{array} \\
\end{array}$ & $\begin{array}{c}\text { Gross return } \\
\left(\text { ETB ha }^{-1}\right)\end{array}$ & $\begin{array}{l}\text { Total cost } \\
\left(\text { ETB ha }^{-1}\right)\end{array}$ & $\begin{array}{l}\text { Net return } \\
\left(\text { ETB ha }^{-1}\right)\end{array}$ \\
\hline $2.5 \mathrm{t} \mathrm{ha}^{-1} \mathrm{VC}+25 \% \mathrm{RDF}$ & 1796.3 & 9879.65 & 3150.50 & 6729.15 \\
\hline $2.5 \mathrm{t} \mathrm{ha}^{-1} \mathrm{VC}+50 \%$ RDF & 1912.0 & 10516.00 & 3177.80 & 7338.20 \\
\hline $2.5 \mathrm{t} \mathrm{ha}^{-1} \mathrm{VC}+75 \% \mathrm{RDF}$ & 2215.0 & 12182.50 & 3321.60 & 8860.90 \\
\hline 2.5 tha $^{-1} \mathrm{FYM}+25 \% \mathrm{RDF}$ & 1860.0 & 10230.00 & 3222.50 & 7007.50 \\
\hline 2.5 tha $^{-1} \mathrm{FYM}+50 \%$ RDF & 2578.3 & 14180.65 & 3562.50 & 10618.15 \\
\hline 2.5 tha $^{-1} \mathrm{FYM}+75 \%$ RDF & 3132.0 & 17226.00 & 3633.20 & 13592.80 \\
\hline $5 \mathrm{t} \mathrm{ha}^{-1} \mathrm{VC}+25 \%$ RDF & 2280.3 & 12541.65 & 4227.00 & 8314.65 \\
\hline $5 \mathrm{t} \mathrm{ha}^{-1} \mathrm{VC}+50 \%$ RDF & 2171.7 & 11944.35 & 4756.00 & 7188.35 \\
\hline $5 \mathrm{t} \mathrm{ha}^{-1} \mathrm{VC}+75 \%$ RDF & 2568.0 & 14124.00 & 5136.00 & 8988.00 \\
\hline 5 tha $^{-1} \mathrm{FYM}+25 \% \mathrm{RDF}$ & 2755.3 & 15154.15 & 4135.00 & 11019.15 \\
\hline 5 tha $^{-1} \mathrm{FYM}+50 \%$ RDF & 3349.7 & 18423.35 & 4226.00 & 14197.35 \\
\hline 5 tha $^{-1} \mathrm{FYM}+75 \%$ RDF & 3668.0 & 20174.00 & 4315.50 & 15858.50 \\
\hline $100 \%$ RDF & 2074.0 & 11407.00 & 3425.00 & 7982.00 \\
\hline Control & 1126.0 & 6193.00 & 2820.00 & 3373.00 \\
\hline
\end{tabular}

$\mathrm{ETB}=$ Ethiopian Birr and the local market price of food barley at harvesting time at Adiyo was 550.00 birr $/ 100 \mathrm{~kg}$ and gross return was the product of market price and grain yield.

${ }^{*} \mathrm{FYM}=$ Farm Yard Manure, RDF = Recommended Dose of inorganic NP Fertilizer, VC = Vermi Compost

Table 7: Partial budget analysis to estimate net benefit as influenced by integrated nutrient management on barley at Ghimbo, Southwestern Ethiopia

\begin{tabular}{|c|c|c|c|c|}
\hline Treatment ${ }^{*}$ & $\begin{array}{c}\text { Yield } \\
\left(\mathrm{kg} \mathrm{ha}^{-1}\right)\end{array}$ & $\begin{array}{c}\text { Gross return } \\
\left(\text { ETB ha }^{-1}\right)\end{array}$ & $\begin{array}{l}\text { Total cost } \\
\left(\text { ETB ha }^{-1}\right)\end{array}$ & $\begin{array}{l}\text { Net return } \\
\left(\text { ETB ha }^{-1}\right)\end{array}$ \\
\hline $2.5 \mathrm{t} \mathrm{ha}^{-1} \mathrm{VC}+25 \%$ RDF & 1525.7 & 7628.5 & 2852.50 & 4776.00 \\
\hline $2.5 \mathrm{t} \mathrm{ha}^{-1} \mathrm{VC}+50 \%$ RDF & 1756.3 & 8781.5 & 3022.50 & 5759.00 \\
\hline $2.5 \mathrm{t} \mathrm{ha}^{-1} \mathrm{VC}+75 \% \mathrm{RDF}$ & 1973.3 & 9866.5 & 3236.00 & 6630.50 \\
\hline 2.5 tha $^{-1} \mathrm{FYM}+25 \%$ RDF & 1640.3 & 8201.5 & 3282.50 & 4919.00 \\
\hline 2.5 tha $^{-1} \mathrm{FYM}+50 \%$ RDF & 2365.7 & 11828.5 & 3488.50 & 8340.00 \\
\hline 2.5 tha $^{-1} \mathrm{FYM}+75 \%$ RDF & 3026.7 & 15133.5 & 3566.00 & 11567.50 \\
\hline $5 \mathrm{t} \mathrm{ha}^{-1} \mathrm{VC}+25 \% \mathrm{RDF}$ & 2066.0 & 10330.0 & 3666.00 & 6664.00 \\
\hline $5 \mathrm{tha}^{-1} \mathrm{VC}+50 \% \mathrm{RDF}$ & 2343.7 & 11718.5 & 4390.00 & 7328.50 \\
\hline $5 \mathrm{t} \mathrm{ha}^{-1} \mathrm{VC}+75 \%$ RDF & 2050.3 & 10251.5 & 4418.00 & 5833.50 \\
\hline 5 tha $^{-1} \mathrm{FYM}+25 \%$ RDF & 2573.7 & 12868.5 & 4225.00 & 8643.50 \\
\hline 5 tha $^{-1} \mathrm{FYM}+50 \%$ RDF & 3293.0 & 16465.0 & 4278.00 & 12187.00 \\
\hline 5 tha $^{-1}$ FYM $+75 \%$ RDF & 3486.0 & 17430.0 & 4322.00 & 13108.00 \\
\hline $100 \%$ RDF & 1900.0 & 9500.0 & 3395.00 & 6105.00 \\
\hline Control & 1155.0 & 5775.0 & 2882.00 & 2893.00 \\
\hline
\end{tabular}

High net return from the foregoing treatments could be attributed to high yield and the low net return was attributed to low yield. From the economic point of view also, it was apparent that $5 \mathrm{t} \mathrm{ha}^{-1} \mathrm{FYM}+50 \%$ of inorganic $\mathrm{NP}$ and $5 \mathrm{t} \mathrm{ha}^{-1} \mathrm{FYM}+75 \%$ of inorganic NP were more profitable than the rest of treatments both at Adiyo and Ghimbo.

\section{CONCLUSIONS}

It can be concluded from the present study that the growth, yield components and yield of barley at both locations responded significantly to integrated application of organic and inorganic fertilizers. Significant increases were recorded in the number of productive tillers $\mathrm{m}^{-2}$, number of grains spike ${ }^{-1}$ and thousand grain weight, aboveground dry biomass and grain yield of barley with the combined application of organic and inorganic 


\section{Mitiku Woldesenbet et al.,}

fertilizers than the application of inorganic NP alone. The higher thousand grain weight, number of grains spike and number of productive tillers $\mathrm{m}^{-2}$ were obtained from the application of either $5 \mathrm{t} \mathrm{ha}^{-1}$ or $2.5 \mathrm{t} \mathrm{ha}^{-1} \mathrm{FYM}$ with different NP rates than the combination with VC both at Adiyo and Ghimbo. From the range of treatments tested, the combined application of $5 \mathrm{t} \mathrm{ha}^{-1} \mathrm{FYM}+75 \%$ recommended rate of inorganic NP gave the highest grain yields both at Adiyo and Ghimbo. Likewise, the economic analysis indicated that the application of $5 \mathrm{t} \mathrm{ha}^{-1} \mathrm{FYM}+$ $75 \%$ inorganic NP gave the highest net return (15,858.50 Ethiopian Birr ha $\left.{ }^{-1}\right)$ at Adiyo and $(13,108.00$ Ethiopian Birr $\mathrm{ha}^{-1}$ ) at Ghimbo. Hence, it is suggested that, farmers in Kaffa Zone could use the combination of FYM, i.e. $5 \mathrm{t} \mathrm{ha}^{-1}$ with $75 \%$ recommended rate of inorganic NP in order to achieve higher grain yield and economic return from barley cultivation. Therefore, in the light of the significant response of barley to integrated fertilizer application, further studies aimed at promoting integrated soil fertility management and formulation of fertilizer recommendations on yearly soil and plant test bases over locations can be useful.

\section{ACKNOWLEDGEMENTS}

Financial support from Ministry of Education (MoE), Ethiopia, for undertaking this study is greatly acknowledged. The material support of Haramaya University and Bonga Agricultural Research Center also deserves special thanks.

\section{REFERENCES}

Abay Ayalew and Tesfaye Dejene (2012). Combined application of organic and inorganic fertilizers to increase yield of barley and improve soil properties at Fereze, in Southern Ethiopia. Innovative Systems Design and Engineering 22(1): 25-34.

Amanuliah J. and Maimoona N. (2007). The response of wheat (Triticum aestivum L.) to farm yard manure and nitrogen under rain fed condition. African Crop Science Proceeding 8:37-40.

Arif, M., Ali, S., Khan, A., Jan T. and M. Akbar (2006). Influence of farm yard manure application on various wheat cultivars. Sarhad Journal of Agriculture 22(1): 27-29.

Banti Gizaw (2009). Geographical location and agroecological variation of Kaffa Zone. MSc. Thesis. Addis Ababa University, Ethiopia. Pp 33-36.

Berhane, L., Hailu G., and Fekadu A. (1996). Barley production and research. In G. Hailu and J. van Leur (eds.). Barley Research in Ethiopia. Past work and future prospects. Proceedings of the First Barley Review work shop, 16- 19 October 1993, Addis Ababa: IAR/ICARDA.

Bouyoucous, C.J. (1951). Reclamation of the hydrometer method for making mechanical analysis of soils. Agronomy Journal 43: 434-438.

Chong, R.S. (2005). Using organic fertilizers. Food and Fertilizer Technology Center, Taiwan.CIAT. Improving fertilizer efficiency and developing soil and water management practices. Integrated Soil Fertility Management, TSBF-CIAT's Achievements and Reflections, 2002-2005.
Sci. Technol. Arts Res. J., April-June 2014, 3(2): 34-42

CIMMYT (International Maize and Wheat improvement Center) (1988). From Agronomic Data to Farmers Recommendations : Economics Training Manual. Completely Revised ed, CIMMYT, Mexico. D.F.

CSA (Central Statistical Agency) (2013). Crop production forecast sample survey, 2013/14 (2006 E.C.), Sept. 12-Oct. 25, 2011. Report on Area and Crop Production forecast for Major Crops (For Private Peasant Holding, Meher Season). Statistical Bulletin, Addis Ababa, Ethiopia.

Dejene M. and Lemlem M. (2012). Integrated agronomic crop managements to improve teff productivity under terminal drought pp. 235- 254. In: I. Md. M. Rahman and H. Hasegawa, Eds., Water Stress, In Tech Open Science.

FAO (food and agriculture organization) (2013). Special reports of crop and food security assessment mission to the Syrian Arab republic. World food program, Rome.

Fageria, N.K. (2009). The use of nutrients in crop plants. CRC Press, Boca Raton, Florida.

Gafar, A. F., Yassin, M., Ibrahim, D. and Yagoob, S. O. (2014). Effect of different (bio organic and inorganic) fertilizers on some yield components of rice (Oryza sativa L.) Universal Journal of Agricultural Research 2(2): 67-70.

Getachew Angachew (2009). Ameliorating effects of organic and inorganic fertilizers on crop productivity and soil properties on reddish- brown soils. Pp. 127150. In: Proceeding of the $10^{\text {th }}$ Conference of the Ethiopian Society of Soil Science. 25-27 March 2009, held at EIAR, Addis Ababa, Ethiopia.

Godara, A.S., Gupta, U.S. and Singh, R. (2012). Effect of integrated nutrient management on herbage, dry fodder yield and quality of oat (Avena sativa L.). Forage Research 38(1): 59-61.

Gomez, K.A. and Gomez, A.A. (1984). Statistical procedures for agricultural research, second edition, John Wiley and Sons Inc. Toronto. 680 pp.

lqbal, A.S., Abbasi, M.K. and Rasool, G. (2002). Integrated plant nutrition system (IPNS) in wheat under rainfed condition of Rawalkot Azad Jammu and Kashmir. Pakistan Journal of Soil Sciences 21: 79-86.

Iqtidar, H., Ayyaz, K.M. and Ahmad, K.E. (2006). Bread wheat varieties as influenced by different nitrogen levels. Zhejiang Journal of Universal Sciences 7: 7078.

Jackson, M.L. (1973). Soil Chemical Analysis. Prentice Hall Grice. Englewood Cliffs, USA. pp.284.

Mahajan, A., Bhagat, R.M. and Gupta, R.D. (2008). Integrated nutrient management in sustainable ricewheat cropping system for food security in India, SAARC Journal of Agriculture 6 (2): 29-32.

Martin, J.H., Walden, R.P., and Stamp, D.L. (2006). Principles of field crop production. Pearson Education, Inc. USA.

Mehta, S. (2005). Integrated nutrient management in wheat (Triticum aestivum) under irrigated condition. Madrass Agricultural Journal 92(7-9): 535-539. 
Mitiku Woldesenbet et al.,

MoARD (Ministry of Agriculture and Rural Development) (2007). Crop Development Department of Crop Variety Register. Issue No. 10. Addis Ababa, Ethiopia. 69 pp.

Mooleki, S.P., Schoenau, J.J., Charles, J.L. and Gwen, G. (2004). Effect of rate, frequency and incorporation of feedlot cattle manure on soil nitrogen availability crop performance and nitrogen use efficiency in eastcentral Saskachwan. Canadian Journal of Soil Science 84: 199-210.

Ofori, J., Bam, R., Sato, K., Masunaga, T., Kamidouzono, A. and Wakatsuki, T. (2005). Rice growth and yield in waste-amended west African lowland soils. Journal of Plant Nutrition 28: 1201-1214.

Ofosu, A.J. and Leitch, M. (2009). Relative efficacy of organic manures in spring barley (Hordeum vulgare L.) production. Australian Journal of Crop Science 3(1):13-19.

Oo, A.N., Banterng, A., Polthanee, A. and Trelo-Ges, V. (2010). The effect of different fertilizers management strategies on growth and yield of upland black glutinous rice and soil property. Asian Journal Plant Sciences 9 (7): 414-422.

Olsen, S.R., Cole C.V., Watanabe F.S. and Dean L.A. (1954). Estimation of available phosphorus in soils by extraction with sodium bicarbonate. U.S. Department of Agriculture 939.

Page, A.L. (1982). Methods of soil analysis. Part II. Chemical and Microbiological Properties. Madison, USA.

Parihar, C.M., Rana, K.S. and Kantwa, S.R. (2010). Nutrient management in pearl millet (Pennisetum glaucum)-mustard (Brassica juncea) cropping system as affected by land configuration under limited irrigation. Indian Journal of Agronomy 55 (3): 191-6.

Pontillas, L., Lugo, E., Malate, R. and Lanioso, A. (2009). Efficacy evaluation of vermi compost and inorganic fertilizer applied in lowland rice. The Threshold 4:6675.

Ranva, R.S. and Singh, K.P. (2006). Effect of integrated nutrient management with vermin compost on productivity of wheat (Triticum aestivum). Indian Journal of Agronomy 26 (2):34-37.
Sci. Technol. Arts Res. J., April-June 2014, 3(2): 34-42

Rasool, R., Kukal, S.S. and Hira, G.S. (2008). Soil organic carbon and physical properties as affected by long-term application of FYM and inorganic fertilizers in maize-wheat cropping system. Soil and Tillage Research 101:31-36.

Saidu, A., Ole, K. and Leye, B.O. (2012). Performance of Wheat (Triticum aestivum L.) as influenced by complementary use of organic and inorganic fertilizers. International Journal of Science and Nature 5(4): 532537.

SAS (Statistical Analysis System) Institute (2003). "SAS Version 9. 1.2 () 2002-2003". SAS Institute, Inc., Cary, North Carolina, USA.

Satyanarayana, V., Prasad, P.V., Murthy, V.R.K. and Boote, K.J. (2002). Influence of integrated use of farmyard manure and inorganic fertilizers on yield and yield components of irrigated lowland rice. Journal of Plant Nutrition 25(10): 2081-2090.

Shata, S.M., Mahmoud, A. and Siam, S. (2007). Improving calcareous soil productivity by integrated effect of intercropping and fertilizer. Research Journal of Agriculture and Biological Sciences 3(6):733-739.

Singh, A.K., Thakur S. and Singh S.K. (1995). Response of rice to nitrogen and zinc application in calcareous situation, International Rice Research Notes 20(2): 1617.

Singh, R. and Agarwal, S.K. (2001). Growth and yield of wheat (Triticum aestivum L.) as influenced by levels of farmyard manure and nitrogen. Indian Journal of Agronomy 46(3): 462-467.

Walkley, A. and Black, C.A. (1954). An examination of the method for determining soil organic matter and proposed modification of the chromic acid titration method. Journal of Soil Science 37: 29-38.

Yavarzadeh, M.R. and Shamsadini, H. (2012). Safe environment by using Flyash and vermicompost on wheat. $\mathrm{Pp}$ 23-25. IN: International Conference on Transport, Environment and Civil Engineering (ICTECE'2012) August 25-26, 2012 Kuala Lumpur (Malaysia) 